\title{
Transglutaminase activity decrease during acclimation to hyposaline conditions in marine seaweed Grateloupia doryphora (Rhodophyta, Halymeniaceae)
}

\author{
Pilar García-Jiménez, Pilar M. Just, Ancor M. Delgado, Rafael R. Robaina*
}

Departamento de Biología, Facultad de Ciencias del Mar, Universidad de Las Palmas de Gran Canaria, ES-35017 Las Palmas de Gran Canaria, Spain

Received 30 January 2006; accepted 15 May 2006

\section{KEYWORDS}

Hyposaline shock;

Marine alga;

Photosynthesis;

Polyamine levels;

Transglutaminase

\begin{abstract}
Summary
Polyamines (PAs), such as diamine putrescine (PUT), triamine spermidine (SPD) and tetraamine spermine (SPM) have been related to environmental stress, including salt stress. A marine red macrophyte alga Grateloupia doryphora (Montagne) Howe was used to investigate the role of PAs during acclimation to moderate hyposaline conditions (incubation $24 \mathrm{~h}$ in 18 psu seawater as compared to $36 \mathrm{psu}$ of natural seawater). The results obtained showed that a moderate hyposaline shock caused an increase in the free fraction of PUT, SPD and SPM, mainly due to a decrease in TGase activity, together with an apparent increase in the L-arginine dependent PAs synthesis (ODC and arginase decreased, and ADC slightly increased). The photosynthetic rate increased in thalli when exposed to free SPD at $18 \mathrm{psu}$, but it did not increase at 36 psu.
\end{abstract}

(c) 2006 Elsevier $\mathrm{GmbH}$. All rights reserved.

\section{Introduction}

The preservation of important cell structures has been assumed to be the result of polyamine $(\mathrm{PA})$

Abbreviations: ADC, L-arginine decarboxylase; ODC, L-ornithine decarboxylase; PAs, polyamines; PUT, putrescine; SPD, spermidine; SPM, spermine; TGase, transglutaminase.

*Corresponding author. Tel.: +34928452 904; fax: +34928452922.

E-mail address: rrobaina@dbio.ulpgc.es (R.R. Robaina). accumulation during salt stress in several higher plants (Erdei et al., 1990, 1996). Aliphatic amines, like diamine putrescine (PUT), triamine spermidine (SPD) and tetraamine spermine (SPM), commonly ascribed as PAs may be found in marine algae in common free and bound compartments (Marián et al., 2000). In spite of intertidal marine algae daily facing salinity fluctuations, reports relating changes in PA contents and their enzyme activities to salinity changes are relatively scarce (Lee, 1998; Lee and Chen, 1998). 
The differences in the PA endogenous levels encountered, as related to physiological events, like salt stress, are determined by novo synthesis, along with the mobilisation between free and bound endogenous PA compartments (Davis et al., 1992). The synthesis of SPD and SPM starts at PUT, which is synthesized by L-ornithine decarboxylase (ODC, EC. 4.1.1.17), or L-arginine decarboxylase (ADC, EC.4.1.1.19). The enzyme arginase (EC. 3.5.3.1) converts L-arginine into L-ornithine. Transglutaminases (TGases, EC.2.3.2.13) may join free PAs to the $\gamma$-carboxyamide moiety of two (bis) glutamine residues of proteins, thus contributing to the bound fraction of PAs in plants (Del Duca et al., 1997; Della Mea et al., 2004).

This work deals with potential changes that moderate hyposaline shocks (18 psu) may promote in the endogenous contents of free and conjugated PAs. To determine whether this situation may benefit the acclimation of the alga, we investigated (i) whether physiological performance might be affected by the changes in Pas; thus, we controlled the effects of PAs on photosynthesis and (ii) whether it was the result of regulation of the metabolism of PAs through related enzymatic activities.

\section{Materials and methods}

The species used in this study, Grateloupia doryphora (Montagne) Howe, is an intertidal red alga living in the tide pools along the northeast coast of Gran Canaria (Canary Islands). Within $2 \mathrm{~h}$ after collection, infertile axes (ca. $4 \mathrm{~g} \mathrm{FW,} n=3$ ) were cultured for $24 \mathrm{~h}$ in $500 \mathrm{~mL}$ aerated glass vessels with $300 \mathrm{~mL}$ of autoclaved seawater at $36 \mathrm{psu}$ or diluted with Milli-Q (A10 gradient) grade water (Millipore) to reach $18 \mathrm{psu}$ as a hyposaline shock at $20 \pm 2{ }^{\circ} \mathrm{C}$ and $30 \mu$ mol photons $\mathrm{m}^{-2} \mathrm{~s}^{-1}$ in a growth chamber.

PAs were extracted, dansylated and quantified by HPLC as previously reported (Sacramento et al., 2004). ODC and ADC enzyme activities were determined in the crude extract from thalli as described elsewhere (Sacramento et al., 2004). Arginase enzyme activity was determined by the spectrophotometric quantification of its product L-ornithine, as described by Primikirios and Roubelakis-Angelakis (1999). To quantify TGase, the crude extract of each sample was precipitated with $70 \%$ ammonium sulphate and desalted through G25. A volume of $250 \mu \mathrm{L}$ was pre-incubated with $10 \mathrm{mMCaCl}_{2}$ for $15 \mathrm{~min}$ at RT, then mixed with
$250 \mu \mathrm{L}$ of an endogenous protein substrate (EPS) prepared by concentrating and desalting the protein in the crude extract of Grateloupia, $140 \mu \mathrm{L}$ of substrate cocktail $(100 \mu \mathrm{L}$ of $0.2 \mathrm{mM}$ SPD from Sigma Co., and $40 \mu \mathrm{L}$ of $\left[{ }^{14} \mathrm{C}\right]-\mathrm{SPD}$, $1.85 \mathrm{MBq} \mathrm{mL}^{-1} \quad 4.14 \mathrm{GBq} \mathrm{mmol}^{-1}$ from Amersham Biosciences, UK), final reaction volume was adjusted to $1 \mathrm{~mL}$ with phosphate buffer $(70 \mathrm{mM}, \mathrm{pH}$ 7). Counts obtained were always corrected with two controls that assessed TGase in EPS and unspecific non-enzymatic linked SPD. TGase activity was determined after $2 \mathrm{~h}$ at $37^{\circ} \mathrm{C}$, though the reaction was seen to be linear for $3 \mathrm{~h}$. Some samples served to check the presence of $\gamma$-glutamyl-SPD residues as an evidence of present transglutaminase activity. In these, the final pellet was redissolved in $100 \mu \mathrm{L}$ of buffer (Tris-glycine $\mathrm{pH}$ $8.8,2 \%$ SDS) instead of scintillant, to count for bound SPD, and loaded on denatured SDS electrophoresis (Bio-Rad miniprotean-III electrophoresis system) in acrylamide gels $(12 \% \mathrm{~T})$ in Tris- $\mathrm{HCl} 3 \mathrm{M}$ $\mathrm{pH}$ 8.8, and Tris-glycine buffer $\mathrm{pH} 8.8$ as a reservoir buffer. After electrophoresis, acrylamide gel was washed with distilled water and protein bands were diced into approximately $1 \mathrm{~mm}$. Proteins were extracted, following the procedures for protein gel digestion with several proteases (Havlis et al., 2003). The amount of SPD was compared before and after $\mathrm{HCl}$ digestion of protease extract, and the significant difference observed was assumed to come from SPD liberation from mono or bis $\gamma$-glutamyl-SPD $(1.7 \pm 0.85$ and $6.85 \pm 3.35 \mu \mathrm{M}$ SPD in samples before and after $\mathrm{HCl}$ hydrolysis, respectively).

Photosynthetic activity was measured with explants incubated for $1 \mathrm{~h}$ in 36 or 18 psu seawater, in the presence or absence of $10^{-6} \mathrm{M}$ of PUT, SPD or SPM. The maximum photosynthetic rate was recorded at saturating $200 \mu \mathrm{mol}$ photons $\mathrm{m}^{-2} \mathrm{~s}^{-1}$ in a Clark-type electrode system (Hansatech, Norfolk, UK) as previously described (Rodrigo and Robaina, 1997).

Statistical analysis was performed with SPSS 13.0 (SPSS Inc., Chicago, USA). Data were analysed by non-parametric Kolmogorov-Smirnov tests to detect differences between treatments.

\section{Results and discussion}

Lee and Chen (1998) reported PUT accumulation in the green alga, Ulva fasciata, and Lee (1998) concluded that this PUT increase was the causal factor of severe hyposaline injury in this, and another six marine species. As seen in Fig. 1, 
the entire free fraction of PUT, SPD and SPM accumulated under hyposaline conditions, together with a decrease in soluble-bound and insoluble PUT, and soluble-bound SPD. The bound and insoluble SPM were apparently invariable. Our red alga appears to be of the species type which preferentially modifies the free fraction of PAs in its reaction to stress conditions. In contrast to the results obtained by Lee (1998), our results are related to moderate hyposaline conditions (Grateloupia is able to grow and regenerate if cultivated in such conditions, Robaina et al., 1990), and, therefore, to physiological events that caused the algae to adapt to toleration levels. As an example, benefits in photosynthetic activity could be ob-
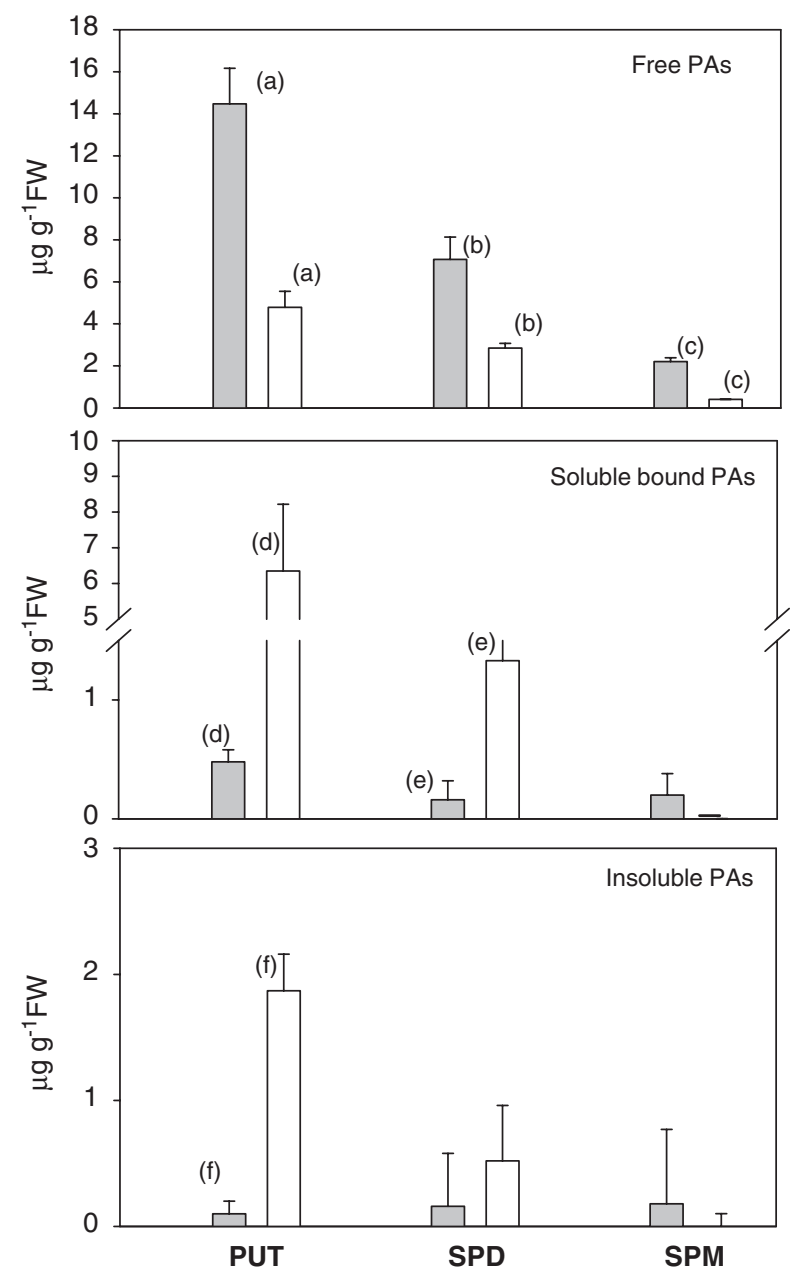

Figure 1. Endogenous levels of PUT, SPD and SPM $\left(\mu \mathrm{g} \mathrm{g}^{-1} \mathrm{FW}\right)$ in all fractions of thalli incubated for $24 \mathrm{~h}$ under hyposaline shock (18 psu. Dark bars) as compared to thalli in natural salinity of seawater ( $36 \mathrm{psu}$. Open bars). Data are the mean \pm SE of $n=4-6$ samples. The same letter denotes significant differences between treatments $(P<0.05)$. tained from free PA accumulation, since thalli subjected to hyposaline treatment showed a general trend to increase their $P_{\max }$ values when incubated with the PUT, SPD or SPM, reaching their highest significant differences in $P_{\max }$ when the explants were incubated in the presence of $10^{-6} \mathrm{M}$ SPD $\quad\left(31.3 \pm 3.1 \mu \mathrm{mol} \quad \mathrm{O}_{2}\right.$ evolved $\mathrm{h}^{-1} \mathrm{~g}^{-1} \mathrm{FW}$ in $18 \mathrm{psu}+\mathrm{SPD}$ as compared to $16.7 \pm 0.5 \mu \mathrm{mol} \mathrm{O}_{2}$ evolved $\mathrm{h}^{-1} \mathrm{~g}^{-1} \mathrm{FW}$ in the control $18 \mathrm{psu}$ without SPD).

Regarding enzymatic activities (Fig. 2), the hyposaline treatment caused a significant decrease in ODC activity, whereas ADC and arginase remained constant. On the contrary, the results provided evidence that a significant decrease in TGase is promoted by hyposaline conditions (fivefold reduction, as the highest modification observed). TGases do exist in plants and microalgae, but, to our knowledge, this is the first report on TGase activity as related to hyposaline stress in a marine macroalga. These variations between free and bound PAs would explain how total PAs were not significantly different between treatments $\left(26.14 \pm 4.5 \mu \mathrm{g} \mathrm{g}^{-1} \mathrm{FW}\right.$ in samples at $18 \mathrm{psu}$ and $19.76 \pm 4.2 \mu \mathrm{g} \mathrm{g}^{-1} \mathrm{FW}$ at $\left.36 \mathrm{psu}\right)$.

In conclusion, a moderate hyposaline shock caused an increase in the free fraction of the common PAs, PUT, SPD and SPM, mainly due to a decrease in TGase activity. This simple mechanism may account for the benefits in physiological performance during acclimation, since the photosynthetic rate increased in thalli when exposed to free PAs.

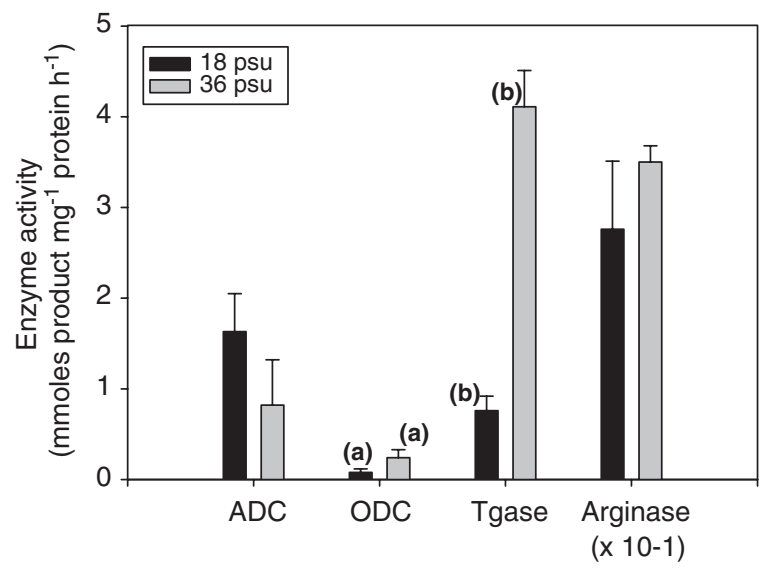

Figure 2. $A D C, O D C$, TGase and arginase $\left(\times 10^{-1}\right)$ enzymatic activities (mmole product $\mathrm{mg}^{-1}$ protein $\mathrm{h}^{-1}$ ) after $24 \mathrm{~h}$ in seawater at 36 and $18 \mathrm{psu}$. The data are the mean of three samples \pm standard error. The same letter denotes significant differences between treatments $(P<0.05)$. 


\section{Acknowledgements}

This work was financially supported by the Spanish Ministerio de Ciencia y Tecnología (Plan Nacional I+D+I), grant no. BFI 2003-01244. The fellowship of the Government of the Canary Islands to PMJ is also acknowledged. We thank Prof. Wolfang Gross (in memoriam) for his helpful suggestions with respect to analysing PA insoluble fractions and his assistance in the TGase determination.

\section{References}

Davis R, Morris D, Coffino P. Microbiol Rev 1992;56: 280-90.

Del Duca S, Bregoli AM, Bergamini C, Seraffini-Fracassini D. Sex Plant Reprod 1997;10:89-95.
Della Mea M, Caparrós-Ruíz D, Claparols I, SerafiniFracassini D, Rigau J. Plant Physiol 2004;135: 2046-54.

Erdei L, Trivedi S, Takeda K, Matsumoto H. J Plant Physiol 1990;137:165-8.

Erdei L, Szegletes Z, Barabas K, Pestenacz A. J Plant Physiol 1996;147:599-603.

Havlis J, Thomas H, Sebela M, Shevchenko A. Anal Chem 2003;75:1300-6.

Lee TM. Plant Sci 1998;138:1-8.

Lee TM, Chen MH. Bot Bull Acad Sin 1998;39:167-74.

Marián FD, García-Jiménez P, Robaina RR. Aquat Bot 2000;68:179-84.

Primikirios NI, Roubelakis-Angelakis KA. Planta 1999;208:574-82.

Robaina RR, García-Reina G, Luque A. Hydrobiologia 1990;204\&205:137-42.

Rodrigo M, Robaina RR. Mar Biol 1997;128:689-94.

Sacramento AT, García-Jiménez P, Alcázar R, Tiburcio A, Robaina RR. J Phycol 2004;50:887-94. 